\title{
Pengaruh Struktur Kepemilikan Terhadap Corporate Value Dengan Keputusan Investasi Dan Pendanaan Sebagai Moderating
}

\author{
Pratiwi Nila Sari ${ }^{{ }^{\star}}$, Cahyadi Husada ${ }^{1}$ \\ ${ }^{1}$ Fakultas Ekonomi dan Bisnis; Universitas Bhayangkara Jakarta Raya; Jl. Raya Perjuangan, \\ Bekasi +622188955882/+622188955871; e-mail: pratiwi@ubharajaya.ac.id, \\ cahyadi.husadha@dsn.ubharajaya.ac.id \\ * Korespondensi: e-mail: pratiwi@ubharajaya.ac.id
}

Submitted: 23/10/2020; Revised: 03/12/2020; Accepted: 08/12/2020; Published: 15/01/2021

\begin{abstract}
This study aims to determine the effect of ownership structure consisting of institutional ownership and managerial ownership on corporate value with investment decisions and funding decisions as moderating variables. The research population is the annual financial statements of manufacturing companies listed on the Indonesia Stock Exchange from 2016 to 2018 as many as 144 companies. This study used an interaction test or moderated regression analysis (MRA). After going through purposive sampling, obtained 41 companies as samples and deserve to be tested at the next stage. The results showed that the company's ownership structure consisting of institutional ownership and managerial ownership had an effect on corporate value. However, the interaction effect between institutional ownership and investment decisions and funding decisions is not proven to increase corporate value or investment decision variables and funding decisions will weaken the relationship between institutional ownership and firm value. Likewise, the results of the interaction test between managerial ownership and investment decisions and funding decisions are not proven to increase corporate value or investment decision variables and funding decisions will weaken the relationship between managerial ownership and corporate value.
\end{abstract}

Keywords: Funding And Firm Value, Investment Decisions, Ownership Structure

\begin{abstract}
Abstrak
Penelitian ini bertujuan untuk mengetahui pengaruh struktur kepemilikan yang terdiri dari kepemilikan institusional dan kepemilikan manajerial terhadap corporate value dengan keputusan investasi dan keputusan pendanaan sebagai variabel moderating. Populasi penelitian yaitu laporan keuangan tahunan perusahaan manufaktur yang terdaftar di Bursa Efek Indonesia dari tahun 2016 - 2018 sebanyak 144 perusahaan. Penelitian ini menggunakan uji interaksi atau moderated regression analysis (MRA). Setelah melalui purposive sampling, diperoleh 41 perusahaan sebagai sampel dan layak untuk di uji pada tahap berikutnya. Hasil penelitian menunjukkan bahwa struktur kepemilikan perusahaan yang terdiri dari kepemilikan institusional dan kepemilikan manajerial berpengaruh terhadap corporate value. Namun, pengaruh interaksi antara kepemilikan institusional dengan keputusan investasi dan keputusan pendanaan tidak terbukti dapat meningkatkan corporate value atau variabel keputusan investasi dan keputusan pendanaan justru akan memperlemah hubungan antara kepemilikan institusional dengan nilai perusahaan. Begitu juga hasil uji interaksi antara kepemilikan manajerial dengan keputusan investasi dan keputusan pendanaan tidak terbukti dapat meningkatkan corporate value atau variabel keputusan investasi dan keputusan pendanaan akan memperlemah hubungan antara kepemilikan manajerial dengan corporate value.
\end{abstract}

Kata Kunci: Pendanaan Dan Nilai Perusahaan, Keputusan Investasi, Struktur Kepemilikan 


\section{Pendahuluan}

Saat ini, Indonesia dihadapkan dengan serangkaian tantangan dalam dunia bisnis yakni terdapat kesepakatan antar negara-negara se-ASEAN dengan nama AEC (ASEAN Economic Community) di bidang tenaga kerja yang diberlakukan mulai tahun 2015. Selain itu, persaingan usaha yang semakin ketat dan kompetitif sehingga banyak bermunculan perusahaanperusahaan baru dengan berbasis Financial Technology (FinTech) atau start up company yang saling bersaing dengan perusahaan yang sudah terlebih dahulu berdiri dan sudah terdaftar di Bursa Efek Indonesia.

Dalam mempertahankan eksistensi dan kelangsungan hidup (going concern), perusahaan dapat melakukan tindakan salah satunya adalah mengembangkan nilai perusahaan (corporate value), antara lain adalah memperhatikan struktur kepemilikan baik kepemilikan saham manajerial dan kepemilikan saham institusi kemudian keputusan investasi dan keputusan pendanaan.

Kepemilikan institusional itu sendiri merupakan kepemilikan saham yang dimiliki oleh institusi lain seperti bank, perusahaan asuransi, perusahaan investasi, dan pihak institusi lainnya. Hal ini berarti bahwa jika kepemilikan saham yang dimiliki oleh institusi tinggi, maka akan meningkatkan pengawasan terhadap perusahaan yang lebih optimal. Kepemilikan saham manajerial adalah proporsi saham biasa yang dimiliki oleh pihak manajemen (Suranta, Eddy dan Masud, 2003). (Siallagan, H. dan Machfoedz, 2006) mengungkapkan jika kepemilikan saham manajerial dalam perusahaan semakin besar maka akan mendorong manajemen untuk meningkatkan kinerjanya. Dengan demikian, kepemilikan saham oleh manajerial diharapkan akan menjadi motivasi bagi pihak manajemen untuk meningkatkan kinerja sehingga berdampak baik bagi peningkatan nilai perusahaan.

Optimalisasi nilai perusahaan dapat dicapai melalui implementasi kebijakan keuangan yang tercermin dari keputusan investasi (investment decision), keputusan pendanaan (financing decision) dan kebijakan dividen (dividend policy) (Hasnawati, 2005). Nilai perusahaan dipengaruhi oleh peluang-peluang investasi yang dibentuk melalui harga pasar saham. Keputusan investasi dilakukan bertujuan untuk mendapatkan laba yang besar, yang risiko dapat dikelola agar nilai perusahaan lebih optimal sehingga dapat meningkatkan kemakmuran pemegang saham (Afzal, 2012). Keputusan investasi dipengaruhi oleh ketersediaan dana perusahaan yang berasal dari sumber pendanaan. Keputusan pendanaan berkaitan dengan penentuan struktur modal yang tepat bagi perusahaan. Dalam suatu perusahaan, keputusan pendanaan bertujuan menentukan sumber dana yang akan digunakan untuk mendanai berbagai alternatif investasi, sehingga nilai perusahaan dapat dimaksimalkan yang terlihat dari harga sahamnya (Septia, 2015).

Kepemilikan institusional bisa terdefinisikan dari persentase proporsi saham yang dimiliki oleh institusi (Nabela, 2012)." Dari definisi kepemilikan institusional tersebut dapat dikatakan bahwa kepemilikan institusional merupakan persentase saham yang dimiliki oleh perusahaan (institusi) yang dapat berfungsi untuk mengontrol kinerja manajemen dan 
memonitor perusahaan tersebut. Dengan dilakukannya monitoring tersebut, diharapkan akan meningkatkan kemakmuran bagi pemegang saham.

Sesuai namanya, kepemilikan manajerial yaitu persentase proporsi saham yang dimiliki oleh manajerial (direksi dan komisaris) dibandingkan dengan jumlah saham yang beredar. Melalui kepemilikan saham manajerial ini, dapat berpengaruh terhadap kinerja manajemen karena jika semakin besar kepemilikan saham manajerial, maka manajemen akan semakin berusaha dalam memaksimalkan kinerjanya dan lebih bertanggung jawab.

Keputusan investasi merupakan keputusan yang penting diantara fungsi manajemen keuangan lainnya dan hampir semua bagian dari perusahaan terpengaruh oleh keputusan investasi. Keputusan investasi merupakan keseluruhan proses perencanaan dan pengambilan keputusan dalam berbagai bentuk investasi yang jangka waktu kembalinya modal lebih dari satu tahun (Subaweh, 2008).

Keputusan pendanaan merupakan keputusan yang terkait dengan struktur keuangan perusahaan (financial structure) yang terdiri dari utang jangka pendek, utang jangka panjang dan modal. Keputusan pendanaan dapat diartikan sebagai keputusan manajer dalam menentukan sumber pendanaan perusahaan baik yang diperoleh dari modal internal (laba ditahan) atau modal eksternal. Keputusan pendanaan merupakan salah satu penyebab timbulnya konflik keagenan antara manajer dan pemegang saham, namun keputusan pendanaan terutama dengan utang bisa menjadi salah satu alternatif untuk menurunkan biaya keagenan karena utang dapat menurunkan kelebihan arus kas perusahaan sehingga akan menurunkan peluang pemborosan oleh manajer (Jensen, M. C., 1976). Kebijakan utang biasanya berhubungan dengan adanya kebutuhan modal untuk investasi atau untuk menutup utang lainnya.

Nilai perusahaan bertujuan untuk meningkatkan kemakmuran bagi pemegang saham dengan cara memaksimumkan nilai sekarang (present value), jika harga saham yang dimiliki oleh pemegang saham meningkat maka keuntungan juga akan meningkat (Sartono, 2011). Dalam persepsi investor, nilai perusahaan sering dikaitkan dengan harga saham. Jika harga saham tinggi maka akan membuat nilai perusahaan tersebut juga tinggi. "Nilai perusahaan menurut (Harmono, 2016) adalah kinerja perusahaan yang tercermin dari harga saham yang dibentuk melalui permintaan dan penawaran pasar modal yang merefleksikan penilaian masyarakat terhadap kinerja perusahaan." Memaksimalkan nilai perusahaan sangat penting karena merupakan tujuan utama perusahaan itu sendiri, dengan begitu perusahaan dapat memaksimalkan kemakmuran pemegang saham dan stakeholders lainnya.

Jika dikaitkan dengan penelitian ini, teori agensi berperan dan mendasari praktek bisnis perusahaan yang akan meningkatkan nilai perusahaan dengan memaksimalkan kemakmuran pemegang saham. Ketika pengambilan keputusan keuangan, teori agensi berperan pada kepemilikan manajerial yang mengutamakan kepentingan pribadi bukan kepentingan pemegang saham atau kepemilikan institusional. 
Teori sinyal (signalling theory) menjelaskan mengapa perusahaan mempunyai dorongan untuk memberikan informasi laporan keuangan pada pihak eksternal agar investor bisa menilai perusahaan dari informasi keuangan perusahaan dan aktivitas perusahaan. Perusahaan dapat meningkatkan nilai perusahaan jika investor mendapatkan informasi keuangan perusahaan yang tidak mengandung unsur asimetri. Salah satu cara yang dapat dilakukan oleh perusahaan untuk mengurangi informasi asimetri adalah dengan memberikan sinyal pada pihak luar, yaitu memberikan informasi keuangan yang dapat dipercaya dan prospek perusahaan yang jelas untuk masa yang akan datang. Dengan demikian, teori ini mendukung pengembangan nilai perusahaan yang dapat memberikan petunjuk bagi investor mengenai prospek perusahaan. Semakin jelas informasi keuangan yang diberikan perusahaan, maka semakin mudah untuk menarik perhatian para investor.

Penelitian yang dilakukan oleh (Tarisma Septi Wardhani, 2012) menunjukan hasil bahwa kepemilikan institusional, keputusan investasi, keputusan pendanaan dan kebijakan dividen secara langsung berpengaruh positif terhadap nilai perusahaan. Keputusan investasi dan keputusan pendanaan juga bisa memoderasi hubungan antara kepemilikan institusional dan nilai perusahaan namun dengan arah negatif, sedangkan kebijakan dividen tidak bisa memoderasi hubungan antara kepemilikan institusional dan nilai perusahaan. Temuan penelitian mengindikasikan bahwa tingkat kepemilikan institusional yang tinggi serta keputusan investasi, keputusan pendanaan dan kebijakan dividen yang optimal dalam perusahaan akan meningkatkan nilai perusahaan.

Penelitian yang dilakukan oleh (Endraswati, 2009) menyatakan bahwa kepemilikan manajerial dan kepemilikan institusional berpengaruh terhadap nilai perusahaan. Pada penelitian ini, peneliti mengembangkan penelitian yang dilakukan oleh (Tarisma Septi Wardhani, 2012) dimana peneliti menambahkan variabel kepemilikan manajerial dengan keputusan investasi dan keputusan pendanaan yang menjadi variabel moderasi tanpa menggunakan variabel kebijakan dividen. Dengan adanya proporsi saham yang dimiliki oleh manajerial dapat memotivasi bagi para jajaran manajer agar lebih meningkatkan kinerja sehingga nilai perusahaan juga meningkat.

Tujuan penelitian ini untuk mengetahui pengaruh struktur kepemilikan yang terdiri dari kepemilikan institusional dan kepemilikan manajerial terhadap corporate value dengan keputusan investasi dan keputusan pendanaan sebagai variabel moderating. Penulis memilih sektor manufaktur sebagai objek penelitian, karena pada sektor manufaktur merupakan salah satu perusahaan dengan jumlah emiten terbanyak di Bursa Efek Indonesia. Sehingga dibutuhkan kebijakan dan keputusan yang tepat dalam hal pengalokasian keuangan perusahaan, baik dalam struktur kepemilikan dan keputusan yang dapat memaksimalkan nilai perusahaan (corporate value) yang dapat menjadikan daya tarik tersendiri bagi para investor dan juga sebagai pertimbangan bagi investor yang ingin berinvestasi pada perusahaan manufaktur. 


\section{Metode Penelitian}

Sebagai populasi penelitian adalah perusahaan manufaktur yang terdaftar di Bursa Efek Indonesia dari tahun 2016 - 2018 yang diperoleh melalui situs resmi Bursa Efek Indonesia yaitu http://www.idx.co.id/. Pengambilan sampel berdasarkan teknik purposive sampling dengan kriteria sampel yaitu perusahaan manufaktur mempublikasikan laporan keuangan, memiliki harga saham, memperoleh laba berturut-turut, memiliki saham institusi dan saham manajerial serta rentang data konsisten. Berikut ini adalah tabel definisi dan indikator variabel penelitian:

Tabel 1. Definisi dan Indikator Variabel

\begin{tabular}{|c|c|c|}
\hline Variabel & Definisi Operasional & Skala \\
\hline \multicolumn{3}{|l|}{ Variabel Independen: } \\
\hline $\begin{array}{ll}\text { 1. } & \text { Kepemilikan } \\
\text { Institusional (X1) }\end{array}$ & $\begin{array}{lll}\text { Persentase saham yang dimiliki oleh investor } & \mathrm{Kl}=\text { Jumlah saham } \\
\text { institusional seperti perusahaan asuransi, } & \text { Institusional } \\
\text { perusahaan investasi, bank, dan institusi } & \text { /Jumlah saham } \\
\text { lainnya (Novitasari, 2011). } & \text { beredar }\end{array}$ & Rasio \\
\hline $\begin{array}{ll}\text { 2. } & \text { Kepemilikan } \\
& \text { Manajerial (X2) }\end{array}$ & $\begin{array}{ll}\text { Proporsi saham biasa yang dimiliki oleh para } & \mathrm{KM}=\text { Jumlah } \\
\text { manajemen (Suranta, E., 2003). } & \text { saham manajerial / } \\
& \text { Jumlah saham } \\
& \text { beredar }\end{array}$ & Rasio \\
\hline $\begin{array}{l}\text { 3. Keputusan Investasi } \\
\text { (X3) } \\
\text { (Variabel } \\
\text { Moderating) }\end{array}$ & $\begin{array}{l}\text { Keputusan investasi merupakan proses EPS = Laba bersih } \\
\text { perencanaan dan pengambilan keputusan / Jumlah saham } \\
\text { dalam berbagai bentuk investasi, yang jangka beredar } \\
\text { waktu kembali modalnya lebih dari satu tahun } \\
\text { (Subaweh, 2008) }\end{array}$ & Rasio \\
\hline $\begin{array}{l}\text { 4. } \text { Keputusan } \\
\text { Pendanaan (X4) } \\
\text { (Variabel }\end{array}$ & $\begin{array}{llll}\text { Keputusan perusahaan yang terkait dengan } & \text { DER }= & \text { Total } \\
\text { komposisi pendanaan (10. Darminto, 2010.Pdf, } & \text { Hutang / Total } \\
\text { n.d.) } & \text { Ekuitas } & \\
\end{array}$ & Rasio \\
\hline Variabel Dependen : & & \\
\hline $\begin{array}{l}\text { Corporate Value } \\
\text { (Nilai Perusahaan) }\end{array}$ & $\begin{array}{l}\text { Nilai perusahaan dapat memberikan } \text { PBV = Harga per } \\
\text { kemakmuran kepada pemegang saham lembar Saham / } \\
\text { apabila harga saham perusahaan meningkat }\end{array}$ & Rasio \\
\hline
\end{tabular}

Sumber : (Verawaty et al., 2016)

Teknik analisis data menggunakan uji interaksi atau moderated regression analysis (MRA) yaitu pengujian yang dilakukan dimana dalam regresinya mengandung unsur interaksi (perkalian dua atau lebih variabel independen) dengan rumus sebagai berikut (Lie, 2009). Rumus persamaan regresinya sebagai berikut: 


$$
Y=a+b_{1} X_{1}+b_{2} X_{2}+b_{3} X_{3}+b_{4} X_{4}+b_{5} X_{1} X_{3}+b_{6} X_{1} X_{4}+b_{7} X_{2} X_{3}+b_{8} X_{2} X_{4}+e
$$

Keterangan:

Y : Corporate value

$\mathrm{X}_{1} \quad$ : Kepemilikan Institusional

$X_{2} \quad$ : Kepemilikan Manajerial

$\mathrm{X}_{1} \mathrm{X}_{3}$ : Interaksi antara Kepemilikan Institusional dan Keputusan Investasi

$\mathrm{X}_{1} \mathrm{X}_{4}$ : Interaksi antara Kepemilikan Institusional dan Keputusan Pendanaan

$\mathrm{X}_{2} \mathrm{X}_{3} \quad$ : Interaksi antara Kepemilikan Manajerial dan Keputusan Investasi

$\mathrm{X}_{2} \mathrm{X}_{4}$ : Interaksi antara Kepemilikan Manajerial dan Keputusan Pendanaan

$b_{1}-b_{8} \quad$ : koefisien regresi a : konstanta

$\mathrm{X}_{3} \quad$ : Keputusan Investasi

$\mathrm{X}_{4} \quad$ : Keputusan Pendanaan

e : variabel pengganggu

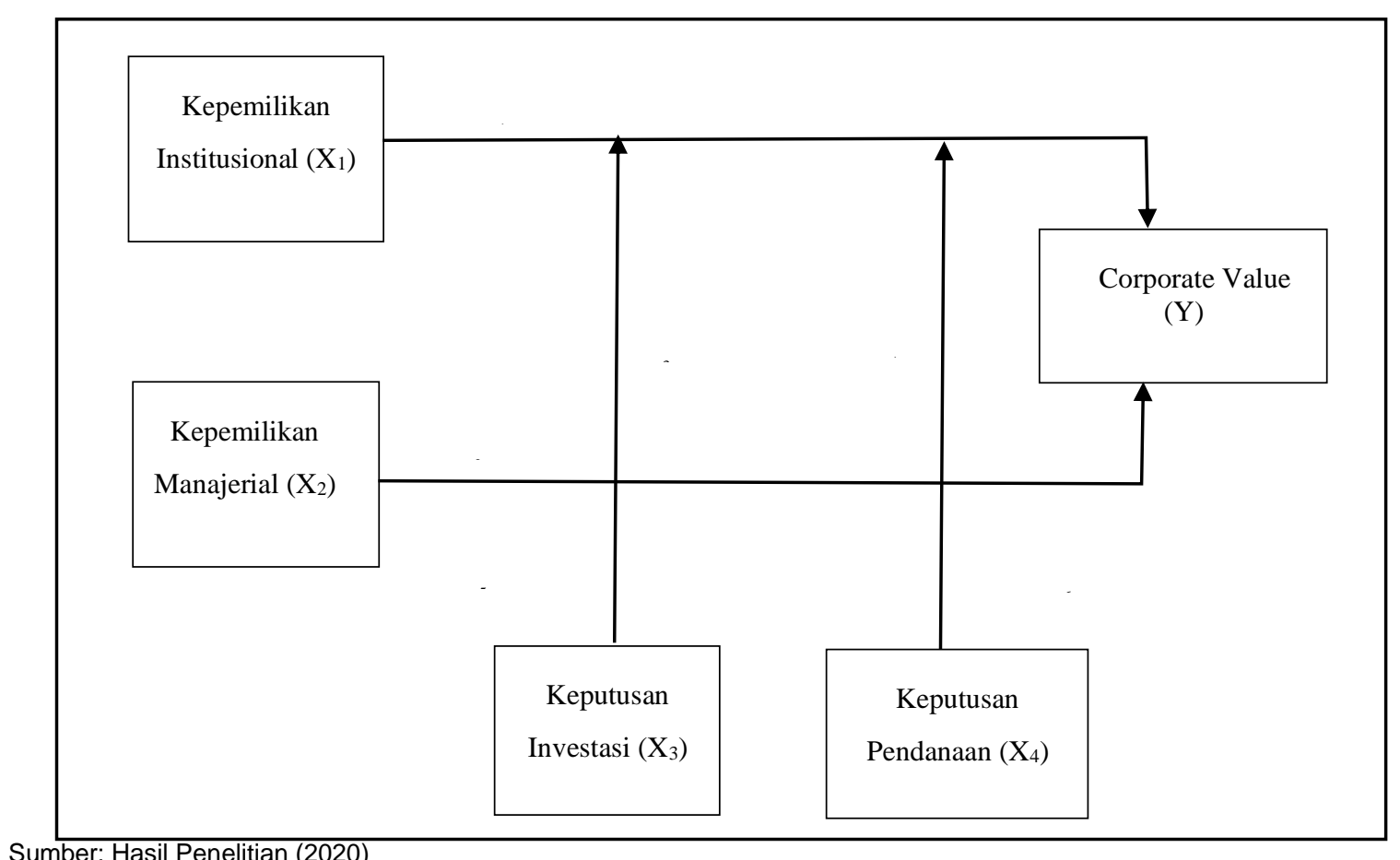

Gambar 1. Kerangka Pemikiran

\section{Hasil dan Pembahasan}

Berikut ini adalah hasil pengujian yang telah dilakukan pada variabel penelitian.

Tabel 2. Hasil Pengujian Data Penelitian

\begin{tabular}{lcccc}
\multicolumn{1}{c}{ Variabel } & Coefficients & $\mathbf{p}$-value & $\mathbf{R}^{\mathbf{2}}$ & Adjusted $\mathbf{R}^{\mathbf{2}}$ \\
\hline (Constant) & & 0.000 & & \\
Institusional & 9.984 & 0.000 & 0.719 & 0.712 \\
Manajerial & 3.399 & 0.002 & 0.229 & 0.209 \\
Interaksi Institusional*Investasi & -3.531 & 0.000 & 0.791 & 0.774 \\
Interaksi Institusional*Pendanaan & -1.063 & 0.000 & 0.727 & 0.705 \\
Interaksi Manajerial*Investasi & -3.084 & 0.000 & 0.548 & 0.511 \\
Interaksi Manajerial*Pendanaan & -1.354 & 0.009 & 0.265 & 0.205
\end{tabular}




\begin{tabular}{lcccc}
\hline \multicolumn{1}{c}{ Variabel } & Coefficients & p-value & $\mathbf{R}^{\mathbf{2}}$ & ${\text { Adjusted } \mathbf{R}^{\mathbf{2}}}$ \\
\hline Asymp. Sig. (2-tailed) & 0.200 & & \\
Run Test & 0.755 & & \\
\hline Observation (N) & \multicolumn{2}{c}{41} & & \\
\hline
\end{tabular}

Dependent Variable: Corp.Value

Signifikansi level 5\%

Sumber : Hasil Pengolahan Data (2020)

\subsection{Pengaruh Kepemilikan Institusional terhadap Corporate Value $\left(\mathrm{H}_{1}\right)$}

Pada hipotesis pertama $\left(\mathrm{H}_{1}\right)$ menyatakan bahwa kepemilikan institusional berpengaruh positif terhadap Corporate Value. Berdasarkan hasil uji regresi menunjukkan bahwa kepemilikan institusional memiliki nilai probabilitas sebesar 0,000 yang mana nilai tersebut lebih rendah atau $p$-value $<\alpha=0,05$ sehingga secara statistik memiliki pengaruh secara signifikan. Dari nilai koefisien regresi diperoleh nilai thitung sebesar 9,984 dapat dikatakan bahwa kepemilikan institusional berpengaruh positif yang mana semakin tinggi kepemilikan institusional akan meningkatkan nilai perusahaan, sehingga hipotesis pertama $\left(\mathrm{H}_{1}\right)$ diterima.

Hasil penelitian ini sejalan dengan (Suranta, Eddy dan Masud, 2003) yang menyatakan bahwa kepemilikan institusional berpengaruh positif terhadap nilai perusahaan. (Fauzan, Nadrisyah, 2012) menyatakan hal serupa yang mana semakin tinggi kepemilikan institusional maka semakin kuat kontrol eksternal perusahaan. Serupa dengan penelitian (Pratiwi \& Kristanti, 2016), yang menyatakan dengan adanya kepemilikan institusional, maka para pemegang saham dan memonitor tim manajemen secara lebih efektif yang nantinya akan meningkatkan nilai perusahaan.

Dengan demikian, semakin tinggi kepemilikan institusional dalam perusahaan, maka pengendalian dari institusi eksternal selaku pemegang saham akan meningkatkan pengawasan, penentuan kebijakan lebih optimal, serta pengendalian efisiensi dan efektivitas atas agency cost yang dapat timbul, sehingga yang pada akhirnya nilai perusahaan juga akan semakin meningkat.

\subsection{Pengaruh Kepemilikan Manajerial terhadap Corporate Value $\left(\mathrm{H}_{2}\right)$}

Hipotesis kedua $\left(\mathrm{H}_{2}\right)$ menyatakan bahwa kepemilikan manajerial berpengaruh positif terhadap Corporate Value. Berdasarkan hasil uji regresi menunjukkan bahwa kepemilikan manajerial memiliki nilai probabilitas sebesar 0,002 yang mana nilai tersebut lebih rendah atau $p$-value $<\alpha=0,05$ sehingga secara statistik memiliki pengaruh secara signifikan. Dari nilai koefisien regresi diperoleh nilai thitung sebesar 3,399 sehingga dapat dinyatakan bahwa kepemilikan institusional berpengaruh positif yang mana semakin tinggi kepemilikan manajerial akan meningkatkan nilai perusahaan, maka hipotesis kedua $\left(\mathrm{H}_{2}\right)$ diterima.

Hasil penelitian ini sejalan dengan (Juhandi et al., 2013) yang menyatakan kepemilikan manajerial akan menyejajarkan kepentingan manajemen dan pemegang saham. Hal serupa dinyatakan oleh (Pratiwi \& Kristanti, 2016) yang menyatakan semakin meningkat proporsi kepemilikan saham manjerial maka semakin baik kinerjanya yang akan berdampak pada 
peningkatan nilai perusahaan. (Siallagan, H. dan Machfoedz, 2006) menyatakan semakin besar kepemilikan manajemen dalam perusahaan maka manajemen akan cenderung untuk berusaha meningkatkan kinerjanya untuk kepentingan pemegang saham dan untuk kepentingannya sendiri. (Verawaty et al., 2016) menyatakan kepemilikan saham oleh manajerial diharapkan manajer akan bertindak sesuai dengan keinginan para prinsipal karena manajer akan termotivasi untuk meningkatkan kinerja dan nantinya dapat meningkatkan nilai perusahaan.

Dengan demikian, meningkatnya kepemilikan manajerial akan menyejajarkan kepentingan sebagai pemegang saham dalam upaya peningkatan corporate value, dan secara tidak langsung akan berpengaruh pada nilai kekayaan yang dimilikinya selaku pemegang saham.

\subsection{Pengaruh Kepemilikan Institusional terhadap Corporate Value dimoderasi oleh Keputusan Investasi $\left(\mathrm{H}_{3}\right)$}

Hipotesis ketiga $\left(\mathrm{H}_{3}\right)$ menyatakan bahwa kepemilikan institusional berpengaruh positif terhadap Corporate Value dengan dimoderasi keputusan investasi. Berdasarkan hasil uji regresi menunjukkan bahwa Kepemilikan Institusional dengan Corporate Value yang dimoderasi Keputusan Investasi memiliki pengaruh secara simultan dengan nilai probabilitas sebesar 0,000 yang mana nilai tersebut lebih rendah atau $p$-value $<\alpha=0,05$, sehingga secara statistik memiliki pengaruh secara signifikan. Dari nilai koefisien regresi, ketiga variabel tersebut secara parsial signifikan memiliki pengaruh terhadap corporate value, karena memiliki level signikansi lebih rendah $p$-value $<\alpha=0,05$. Namun, variabel interaksi antara kepemilikan institusional dan investasi diperoleh nilai thitung $-3,531$. Pengaruh secara langsung keputusan investasi dapat meningkatkan nilai perusahaan, namun interaksi antara kepemilikan institusional dengan keputusan investasi tidak terbukti dapat meningkatkan corporate value atau variabel keputusan investasi justru akan memperlemah hubungan antara kepemilikan institusional dengan nilai perusahaan.

Hasil penelitian ini sejalan dengan (Keown, 2010) yang menyatakan bahwa kebijakan investasi ataupun dividen yang buruk akan mengakibatkan para investor bereaksi dan membuat harga saham menjadi turun, sehingga nilai perusahaan juga akan turun dan sebaliknya. (Triani \& Tarmidi, 2019) menyatakan bahwa keputusan Pendanaan dan Kebijakan Dividen dapat meningkatkan nilai perusahaan sedangkan Keputusan Investasi tidak. Berdasarkan hal tersebut dapat dijelaskan bahwa investor tidak bereaksi signifikan terhadap keputusan investasi pada Perusahaan, maka Nilai Perusahaan tidak dipengaruhi oleh keputusan investasi. Hal serupa dinyatakan oleh (Salama et al., 2019) yang mana keputusan investasi tidak berpengaruh signifikan terhadap nilai perusahaan pada industri perbankan. Tidak berpengaruhnya keputusan investasi disebabkan adanya faktor ketidakpastian di masa depan, ketidakpastian tersebut berupa adanya perubahan teknologi, kondisi sosial ekonomi maupun kebijakan-kebijakan pemerintah.

Dengan demikian, keputusan investasi yang tepat seharusnya mampu mendorong kepemilikan institusional untuk memperoleh corporate value. Namun dalam penelitian ini 
peranan nilai EPS tidak mampu meyakinkan investor untuk mengambil keputusan investasi secara tepat yang bisa disebabkan karena adanya ketidakpastian di masa depan dalam hal sosial-ekonomi, maupun asimetri informasi yang diperoleh investor, bahkan bagi investor dengan kepemilikan institusional untuk menaikan corporate value yang dimilikinya.

\subsection{Pengaruh Kepemilikan Institusional terhadap Corporate Value dimoderasi oleh} Keputusan Pendanaan $\left(\mathrm{H}_{4}\right)$

Hipotesis keempat $\left(\mathrm{H}_{4}\right)$ menyatakan bahwa kepemilikan institusional berpengaruh positif terhadap Corporate Value dengan dimoderasi keputusan pendanaan. Berdasarkan hasil uji regresi menunjukkan bahwa Kepemilikan Institusional dengan Corporate Value yang dimoderasi Keputusan pendanaan memiliki pengaruh secara simultan dengan nilai probabilitas sebesar 0,000 yang mana nilai tersebut lebih rendah atau $p$-value $<\alpha=0,05$, sehingga secara statistik memiliki pengaruh secara signifikan. Dari nilai koefisien regresi secara parsial peranan variabel keputusan pendanaan dan interaksinya tidak memiliki pengaruh signifikan terhadap corporate value, karena memiliki level siginikansi lebih besar atau $p$-value $\alpha=0,05$. Bahkan variabel interaksi antara kepemilikan institusional dan keputusan pendanaan diperoleh nilai thitung $-1,063$. Pengaruh secara langsung keputusan pendanaan dapat meningkatkan corporate value, tetapi interaksi antara kepemilikan institusional dengan keputusan pendanaan tidak terbukti dapat meningkatkan corporate value maupun variabel keputusan pendanaan, tetapi akan memperlemah hubungan antara kepemilikan institusional dengan corporate value.

Hasil penelitian ini mendukung penelitian (Saputra \& Wardhani, 2017), yang menyatakan bahwa semakin besar tingkat utang, semakin besar kemungkinan terjadinya ketidakmampuan perusahaan untuk membayar kewajibannya dan umumnya investor lebih menyukai perusahaan dengan risiko kebangkrutan yang rendah. Penelitian (Sujoko, 2017) menyimpulkan bahwa kebijakan pendanaan dengan utang berpengaruh negatif dan signifikan terhadap nilai perusahaan. (Sumarau, 2019) dalam hasil penelitiannya menyebutkan bahwa keputusan pendanaan (DER) memberikan efek negatif dan tidak signifikan sehingga akan mengurangi nilai perusahaan (PBV). Hasil penelitian (Salama et al., 2019) menyebutkan bahwa tidak berpengaruhnya keputusan pendanaan disebabkan oleh adanya kekhawatiran investor akan risiko kebangkrutan akibat penggunaan utang sebagai sumber pendanaan sehingga menurunkan minat investor untuk berinvestasi.

Dengan demikian, keputusan pendanaan yang dibiayai dengan hutang meskipun dikelola oleh kepemilikan institusional tidak mampu meningkatkan corporate value. Adanya risiko terjadi kondisi default, financial distress maupun gejolak ekonomi-sosial dapat menurunkan kemampuan perusahaan untuk memenuhi kewajiban hutangnya, terlebih investor lebih menyukai perusahaan dengan risiko financial distress rendah.

\subsection{Pengaruh Kepemilikan Manajerial terhadap Corporate Value dimoderasi oleh Keputusan Investasi $\left(\mathrm{H}_{5}\right)$}

Hipotesis kelima $\left(\mathrm{H}_{5}\right)$ menyatakan bahwa kepemilikan manajerial berpengaruh positif terhadap Corporate Value dengan dimoderasi keputusan investasi. Berdasarkan hasil uji 
regresi menunjukkan bahwa Kepemilikan manajerial dengan Corporate Value yang dimoderasi Keputusan Investasi memiliki pengaruh secara simultan dengan nilai probabilitas sebesar 0,000 yang mana nilai tersebut lebih rendah atau $p$-value $<\alpha=0,05$, sehingga secara statistik memiliki pengaruh secara signifikan. Dari nilai koefisien regresi ketiga variabel tersebut signifikan secara parsial memiliki pengaruh terhadap corporate value, karena memiliki level signikansi lebih rendah $p$-value < $\alpha=0,05$. Namun, variabel interaksi antara kepemilikan manajerial dan keputusan investasi diperoleh nilai thitung $-3,084$. Pengaruh secara langsung keputusan investasi dapat meningkatkan nilai perusahaan, namun interaksi antara kepemilikan manajerial dengan keputusan investasi tidak terbukti dapat meningkatkan corporate value dan variabel keputusan investasi tetapi akan memperlemah hubungan antara kepemilikan manajerial dengan corporate value.

Hasil penelitian antara hubungan secara langsung antara keputusan investasi maupun kepemilikan manajerial terhadap corporate value sejalan dengan penelitian (Snow et al., 2001) yang menyatakan keputusan investasi berpengaruh terhadap nilai perusahaan dengan arah hubungan positif, kenaikan investasi akan meningkatkan nilai perusahaan. Yakni apabila tingkat investasi disebuah perusahaan tinggi maka akan meningkatkan kepercayaan investor terhadap perusahaan tersebut karena pertumbuhan investasi tersebut dapat dipersepsikan sebagai sinyal positif bagi para investor, selain itu peningkatan investasi ini akan dianggap sebagai pertumbuhan perusahaan dimasa yang akan datang dan penentu nilai perusahaan. (Bakri Katti, 2020) yang mengatakan bahwa keputusan yang tepat yang dilakukan oleh seorang manajer dalam membuat keputusan investasi akan menciptakan suatu peningkatan nilai pada perusahaan sehingga akan meningkatkan nilai perusahaan. Hal ini dikarenakan apabila seorang manajer yang berhasil menciptakan keputusan investasi yang tepat maka akan menghasilkan kinerja yang optimal yang nantinya akan dapat meningkatkan nilai perusahaan. Namun dalam penelitian ini interaksi antara kepemilikan manajerial dengan keputusan investasi tidak terbukti dapat meningkatkan corporate value dan variabel keputusan investasi

Dengan demikian, keputusan investasi yang kepemilikan perusahaannya dimiliki oleh manajemen tidak terbukti mampu meningkatkan corporate value. Hal ini dapat diakibatkan karena cenderung sulitnya atau tidak tepatnya manajer dalam pengambilan keputusan, adanya conflict of interest oleh manajemen, dan adanya adanya asimetri informasi antara manajemen perusahaan dan pihak-pihak yang berkepentingan dengan informasi tersebut sebagaimana dalam teori sinyal (signaling theory).

\subsection{Pengaruh Kepemilikan Manajerial terhadap Corporate Value dimoderasi oleh Keputusan Pendanaan $\left(\mathrm{H}_{6}\right)$}

Hipotesis keenam $\left(\mathrm{H}_{6}\right)$ menyatakan bahwa kepemilikan manajerial berpengaruh positif terhadap Corporate Value dengan dimoderasi keputusan pendanaan. Berdasarkan hasil uji regresi menunjukkan bahwa Kepemilikan Institusional dengan Corporate Value yang dimoderasi Keputusan pendanaan memiliki pengaruh secara simultan dengan nilai probabilitas sebesar 0,009 yang mana nilai tersebut lebih rendah atau $p$-value $<\alpha=0,05$, sehingga secara 
statistik memiliki pengaruh secara signifikan. Dari nilai koefisien regresi secara parsial peranan variabel keputusan pendanaan dan interaksinya tidak memiliki pengaruh signifikan terhadap corporate value, karena memiliki level siginikansi lebih besar atau $p$-value $>\alpha=0,05$. Bahkan variabel interaksi antara kepemilikan manajerial dan keputusan pendanaan diperoleh nilai thitung $-1,354$. Pengaruh secara langsung keputusan pendanaan dapat meningkatkan corporate value, tetapi interaksi antara kepemilikan manajerial dengan keputusan pendanaan tidak terbukti dapat meningkatkan corporate value maupun variabel keputusan pendanaan, tetapi justru akan memperlemah hubungan antara kepemilikan manajerial dengan corporate value.

Hasil penelitian antara hubungan secara langsung antara keputusan pendanaan maupun kepemilikan manajerial terhadap corporate value sejalan dengan penelitian (Ambarwati, 2010), yang menyatakan bahwa perusahaan harus membuat keputusan pendanaan yang paling optimal agar hutang dan ekuitas benar-benar kombinasi yang dapat menghasilkan keuntungan atau keuntungan bagi perusahaan itu pada akhirnya memaksimalkan nilai perusahaan. Hal serupa juga dinyatakan oleh (Triani \& Tarmidi, 2019), bahwa tingginya jumlah hutang atau pinjaman merupakan salah satu indikator bahwa perusahaan memiliki kinerja, dan kinerja yang baik memberi prospek kepercayaan kepada bank dan investor bereaksi terhadap nilai pinjaman sehingga nilai perusahaan juga tinggi. Namun dalam penelitian ini interaksi antara kepemilikan manajerial dengan keputusan pendanaan tidak terbukti dapat meningkatkan corporate value dan variabel keputusan investasi sebagaimana yang dinyatakan oleh (Brealey, 2007), menyatakan bahwa manajer akan berusaha meningkatkan tingkat utang sampai pada suatu titik di mana nilai perlindungan pajak bunga tambahan benar-benar terimbangi oleh tambahan biaya masalah keuangan, artinya penggunaan utang akan meningkatkan nilai perusahaan hanya sampai pada suatu titik optimal. Setelah titik tersebut penggunaan utang justru dapat menurunkan nilai perusahaan karena kenaikan keuntungan dari penggunaan utang tidak sebanding dengan biaya finansial atau kewajiban biaya bunga dari utang.

Dengan demikian, keputusan pendanaan yang kepemilikan perusahaannya dimiliki oleh manajemen tidak terbukti mampu meningkatkan corporate value. Hal ini dapat diakibatkan karena pada titik optimal tertentu penggunaan hutang tidak sebanding dengan biaya finansial atau kewajiban atas biaya bunga hutang tersebut, pengambilan keputusan oleh manajemen yang tidak cermat atas penggunaan hutang justru turut memperburuk turunnya corporate value. Kondisi ekonomi-sosial dari pihak eksternal, kebijakan pemerintah terhadap suku bunga pinjaman turut andil dalam menentukan keputusan manajemen selaku investor dalam pendanaan.

\section{Kesimpulan}

Berdasarkan hasil penelitian, maka dapat disimpulkan bahwa struktur kepemilikan perusahaan yang terdiri dari kepemilikan institusional dan kepemilikan manajerial berpengaruh terhadap corporate value. Namun, pengaruh interaksi antara kepemilikan institusional dengan 
keputusan investasi dan keputusan pendanaan tidak terbukti dapat meningkatkan corporate value atau variabel keputusan investasi dan keputusan pendanaan justru akan memperlemah hubungan antara kepemilikan institusional dengan nilai perusahaan. Begitu juga hasil uji interaksi antara kepemilikan manajerial dengan keputusan investasi dan keputusan pendanaan tidak terbukti dapat meningkatkan corporate value atau variabel keputusan investasi dan keputusan pendanaan akan memperlemah hubungan antara kepemilikan manajerial dengan corporate value.

\section{Ucapan Terima Kasih}

Pada kesempatan ini, saya ingin mengucapkan terima kasih kepada Kementerian Riset dan Teknologi / Badan Riset dan Inovasi Nasional atas dana hibah penelitian yang saya terima di tahun 2020. Dan juga untuk Lembaga Penelitian, Pengabdian Kepada Masyarakat dan Publikasi (LPPMP) Ubhara Jaya yang mendukung dalam memonitor selama proses pelaksanaan proses penelitian hibah dikti.

\section{Daftar Pustaka}

10. Darminto, 2010.pdf. (n.d.).

Afzal, A. dan A. R. (2012). Pengaruh Keputusan Investasi, Keputusan Pendanaan, dan Kebijakan Dividen terhadap Nilai Perusahaan. Diponegoro Journal of Accounting, 1(2), 9.

Ambarwati, S. D. A. (2010). Manajemen Keuangan Lanjutan. Graha Ilmu.

Bakri Katti, S. W. (2020). Pengaruh Keputusan Investasi Dan Keputusan Pendanaan Terhadap

Nilai Perusahaan. JURNAL EKOMAKS: Jurnal IImu Ekonomi, Manajemen, Dan Akuntansi, 9(1), 30-38. https://doi.org/10.33319/jeko.v9i1.51

Brealey, et. al. (2007). Dasar-dasar Manajemen Keuangan. Erlangga.

Endraswati, H. (2009). Pengaruh Struktur Kepemilikan dan Kebijakan Dividen terhadap Nilai

Perusahaan dengan Kebijakan Hutang sebagai Variabel Moderating pada Perusahaan di BEI. STAIN.

Fauzan, Nadrisyah, A. (2012). Pengaruh Struktur Kepemilikan dan Kinerja Keuangan Early Warning System Terhadap Nilai Perusahaan. Jurnal Akuntansi, 2(1), 64-75.

Harmono. (2016). Manajemen Keuangan Berbasis Balanced Scorecard Pendekatan Teori, Kasus, dan Riset Bisnis. Bumi Aksara.

Hasnawati, S. (2005). Dampak Set Peluang Investasi Terhadap Nilai Perusahaan Publik di Bursa Efek Jakarta. Jaai, 9(2), 117-126.

Investasi, P. K., Pendanaan, K., Kebijakan, D. A. N., Di, T., Periode, B. E. I., Ekonomi, F., \& Manajemen, J. (2019). Pengaruh Keputusan Investasi, Keputusan Pendanaan Dan Kebijakan Dividen Terhadap Nilai Perusahaan Pada Industri Perbankan Yang Terdaftar Di Bei Periode 2014-2017. Jurnal EMBA: Jurnal Riset Ekonomi, Manajemen, Bisnis Dan Akuntansi, 7(3), 2651-2660. https://doi.org/10.35794/emba.v7i3.23715

Jensen, M. C., dan W. H. M. (1976). Theory of the Firm: Managerial Behavior, Agency Cost, 
and Ownership Structure. Journal of Financial Economics, 3(4), 305-306.

Juhandi, N., Sudarma, M., Aisjah, S., \& Rofiaty. (2013). The Effects of Internal factors and Stock Ownership Structure on Dividend Policy on Company's Value A Study on Manufacturing Companies Listed on the Indonesia Stock Exchange (IDX). International Journal of Business and Management Invention, 2(11), 6-18. http://www.pubmedcentral.nih.gov/articlerender.fcgi?artid=2352227\&tool=pmcentrez\&rend ertype $=$ abstract

Keown, et al. (2010). Manajemen Keuangan: Prinsip dan Penerapan Jilid 2. Indeks.

Lie, L. (2009). Penggunaan MRA dengan Spss untuk Menguji Pengaruh Variabel Moderating terhadap Hubungan antara Variabel Independen dan Variabel Dependen. Jurnal $\begin{array}{llll}\text { Teknologi Informasi } & \text { DINAMIK, }\end{array}$ https://www.unisbank.ac.id/ojs/index.php/tti1/article/view/95/90

Nabela, Y. (2012). Pengaruh Kepemilikan Institusional, Kebijakan Dividen, dan Profitabilitas Terhadap Kebijakan Utang Pada Perusahaan Property dan Real Estate di BEI. Jurnal Manajemen, 1(1), 1-8.

Novitasari, E. (2011). Implikasi Struktur Kepemilikan terhadap Nilai Perusahaan: Dengan Kebijakan Dividen sebagai Variabel Intervening pada Perusahaan Go Public di Bursa Efek Indonesia (BEI). Sekolah Tinggi Ekonomi Perbanas.

Pratiwi, M. I., \& Kristanti, F. (2016). Pengaruh Kepemilikan Manajerial, Kepemilikan Institusional, dan Leverage Terhadap Nilai Perusahaan. E-Proceeding of Management, 3(3), 3191-3197.

Saputra, A. A. D., \& Wardhani, R. (2017). Pengaruh efektivitas dewan komisaris, komite audit dan kepemilikan institusional terhadap efisiensi investasi. Jurnal Akuntansi \& Auditing Indonesia, 21(1), 24-36. https://doi.org/10.20885/jaai.vol21.iss1.art3

Sartono, A. (2011). Manajemen Keuangan Teori dan Aplikasi. BPFE.

Septia, A. W. (2015). Pengaruh Profitabilitas, Keputusan Investasi, Keputusan Pendanaan, dan Kebijakan Dividen Terhadap Nilai Perusahaan Pada Perusahaan Manufaktur yang terdaftar di BEI. Universitas Negeri Yogyakarta.

Siallagan, H. dan Machfoedz, M. (2006). Mekanisme Corporate Governance, Kualitas Laba dan Nilai Perusahaan. Simposium Nasional Akuntansi IX.

Snow, V., Lascher, S., \& Mottur-Pilson, C. (2001). The Evidence Base for Management of Acute Exacerbations of COPD. Chest, 119(4), 1185-1189. https://doi.org/10.1378/chest.119.4.1185

Subaweh, I. (2008). Agency Theory dalam Pemerintahan Daerah. http://nustaffsite.gunadarma.ac.id

Sujoko, S. (2017). Pengaruh Struktur Kepemilikan, Strategi Diversifikasi, Leverage, Faktor Intern Dan Faktor Ekstern Terhadap Nilai Perusahaan (Studi Empirik Pada Perusahaan Manufaktur Dan Non Manufaktur Di Bursa Efek Jakarta). EKUITAS (Jurnal Ekonomi Dan Keuangan), 11(2), 236. https://doi.org/10.24034/j25485024.y2007.v11.i2.2236 
Sumarau, S. K. (2019). the Effect of Investment Decisions, Funding Decisions, and Profitability on Manufacturing Company Value in Indonesia Stock Exchange 2015-2018 Period. Accountability, 8(2), 85. https://doi.org/10.32400/ja.24759.8.2.2019.85-90

Suranta, E., dan P. P. M. (2003). Analisis Hubungan Struktur Kepemilikan Manajerial, Nilai Perusahaan dan Investasi dengan Model Persamaan Linear Simultan. Jurnal Riset Akuntansi Indonesia, 6(1).

Suranta, Eddy dan Masud, M. (2003). Analisis Struktur Kepemilikan, Nilai Perusahaan, Investasi, dan Ukuran Dewan Direksi. Simposium Nasional Akuntansi VI, 214-226.

Tarisma Septi Wardhani, G. C. \& A. F. R. (2012). Pengaruh Kepemilikan Institusional Terhadap Nilai Perusahaan Dengan Keputusan Investasi ,. Jurnal IImiah Akuntansi, Keuangan Dan Pajak, 1(2), 93-110.

Triani, N., \& Tarmidi, D. (2019). Firm Value: Impact of Investment Decisions, Funding Decisions and Dividend Policies. International Jurnal Of Academic Research in Accounting, Finance, and Management Sciences, 9(2), 158-163. https://doi.org/10.6007/IJARAFMS/v9-i2/6107

Verawaty, V., Merina, C. I., \& Kurniawati, I. (2016). Analisis Pengembangan Corporate Value berdasarkan Keputusan Investasi dan Pendanaan, Struktur Kepemilikan serta Kebijakan Dividen pada Perusahaan Manufaktur yang Terdaftar di Bursa Efek Indonesia. Berkala Akuntansi Dan Keuangan Indonesia, 1(1), 15-34. https://doi.org/10.20473/baki.v111.1695

Wijaya, L. R.P., Bandi, dan A. W. (2010). Pengaruh Keputusan Investasi, Keputusan Pendanaan, dan Kebijakan Dividen Terhadap Nilai Perusahaan. Simposium Nasional Akuntansi XIII. 